\title{
Hüsn ü Aşk’ta anlam çeşitliliği yönünden kuşlar
}

\section{Özlem GÜNEȘ}

Ayşe YEŞIL ${ }^{2}$

\section{Nurseda ÖĞRETEN3} APA: Güneş, Ö.; Yeşil, A.; Öğreten, N. (2019). Hüsn ü Aşk’ta anlam çeşitliliği yönünden kuşlar.
RumeliDE Dil ve Edebiyat Araşttrmalarl Dergisi, (Ö5), 239-26o. DOI: 10.29000/rumelide.606147.

\section{$\ddot{O} \mathbf{z}$}

Şeyh Gâlib’in en önemli eseri olarak kabul edilen Hüsn ü Aşk; Osmanlı şiir kuşlarını ele alması yönüyle de zengin bir mesnevîdir. Divan şiiri geleneğinde işlenmiş kuşlar, Sebk-i Hindî akımının etkisinde olan şairin tavsifinde farklı yönleriyle de tezâhür etmiştir. Bu çalışmanın amacı; Osmanlı şiir kuşlarının Şeyh Gâlib’in Hüsn ü Aşk mesnevîsinde nasıl ele alınmış olduğunu gözler önüne sermektir. Çalışmada Muhammed Nur Doğan tarafından hazırlanan Şeyh Gâlib Hüsn ü Aşk Metin, Düzyazıya Çeviri Notlar ve Açıklamalar adlı kitap temel alınmıştır. Öncelikle; metin, tarama ve tahlil yöntemleriyle incelenecek, mesnevideki olay örgüsü içinde kuşların ne şekilde ele alındığı saptanacak ve Gâlib’in kuşlarla ilgili geleneksel kullanımla benzeşen ve bu kullanımdan ayrılan yönleri ortaya koyulacaktır. Hüsn ü Aşk metni, somuttan soyuta uzanan birçok anlam katmanını içinde barındırır. Bu katmanlar muhtelif yorum ve okumalara açık; aynı zamanda da gerçek dünya ile bağlantılı bir durum arz eder. Gelenek içerisinde çoğunlukla olumlu tasvirlerle ve hayal dünyası içerisinde anlatılan kaknüs kuşu; bu mesnevîde Osmanlı İstanbul'unun kahve köşelerinde zaman harcayan ve kendileri bir şey üretmedikleri hâlde, zamanın en büyük söz ustaları ile mukayese hâlinde olan şair bozuntularını eleştirmek için somuta indirgenerek kullanılmıştır. Bu örnek, soyut ve somut anlamlar arasındaki geçişlerin mesnevîdeki en çarpıcı örneklerinden biridir. Nihâî hedef olarak, Gâlib’in şiirlerindeki bu çok katmanlılık ve geçişler , kuşlar temelinde ele alıp açıklanmaya çalışılacaktır.

Anahtar kelimeler: Şeyh Gâlib, Hüsn ü Aşk, kuşlar.

\section{Birds in Hüsn ü Aşk in terms of variety of meaning}

\begin{abstract}
Hüsn ü Aşk, considered to be the most important work of Şeyh Gâlib, is also a prosperous masnavi in the way of its reviewing of birds of Ottoman poetry. The birds rewieved in the tradition of Divan poetry, have appeared in a different form in the portraiture of the poet in the impact of Sebk-i Hindî movement. The goal of this work is revealing how the birds of Ottoman poetry have reviewed in the masnavi of Hüsn ü Aşk by Şeyh Gâlib. This work grounds on the book named "Şeyh Gâlib Hüsn ü Aşk Metin, Düzyazıya Çeviri Notlar ve Açılamalar” which is prepared by Muhammed Nur Doğan.
\end{abstract}

Dr. Öğrt. Üyesi, İstanbul Sabahattin Zaim Üniversitesi, İslami İlimler Fakültesi, İslam Tarihi ve Sanatları Bölümü (İstanbul, Türkiye), ozlem.gunes@izu.edu.tr, ORCID ID: 0000-0002-3406-9503 [Makale kaylt tarihi: 16.06.2019-kabul tarihi:18.08.2019; DOI: 10.29000/rumelide.606147]

2 YL Öğrencisi, 29 Mayıs Üniversitesi, Sosyal Bilimler Enstitüsü (İstanbul/ Türkiye), aayse.yesil@gmail.com, ORCID ID: 0000-0002-3476-9999.

3 YL Öğrencisi, Yıldız Teknik Üniversitesi, Sosyal Bilimler Enstitüsü (İstanbul/Türkiye), nurseda.ogreten@gmail.com, ORCID ID: 0000-0001-6910-2281. 


\begin{abstract}
Firstly, the text will be investigated by the methods of scanning and analyze, it will be appointed how the birds are reviewed through the plot, and the similar and different aspects of Gâlib on birds with/than the traditional using will be revealed. Hüsn ü Aşk has lots of semantic stratums extending from the abstract to concrete. This semantic straums are open to various readings and interpretations, and also connected with the real world. The Kaknüs bird which has been mostly pictured in a positive imagery in the tradition, is used in this masnavi to embody and criticize the poetasters who spend their time in the coffee shops of Ottoman İstanbul without doing anything notwithstanding seeing themselves as the rivals of the masters of poetry of their time. This example is one of the most striking examples of the transition between abstract and concrete meanings in masnavi. As the final goal, this semantic straums and transitions of Gâlib's poetry will be trying to explain based on birds issue.
\end{abstract}

Keywords: Şeyh Gâlib, Hüsn ü Aşk, birds.

\title{
Giriş
}

Toplumların millî değerlerini oluşturan kültürel ögelerin ortaya çıkarılması, bu unsurların kullanımlarının devamının sağlanmasının yanı sıra kültürün diğer nesillere aktarımı hususunda da ciddi öneme sahiptir.

Kültürün bir yansıtıcısı olarak kuşlar dünya medeniyetlerinde olduğu gibi Türk toplulukları için de yadsınamayacak bir yere sahip olmuştur. İslamiyet’ten önceki dönemlerde Türkler kuşları ruhun simgesi olarak kutlu kabul etmişlerdir (Çoruhlu, 2002: 151). Oğuzlarda her Türk boyunun bir ongun kuşu bulunmaktadır ve bu kuşlara büyük önem verilmiş olup her kabile bir kuşu kendisi için bir sembol ve arma edinmiştir (Ögel, 1993: 32-33; 355-368). Diğer taraftan hâkimiyet sembolü olarak da kartalın Türk kavimlerinde yaygın bir biçimde kullanılması ve Türklerden diğer batı kavimlerine yayılması da kuşun sembol olarak Türk kültüründeki yerinin belirlenmesi açısından dikkate değerdir (Kafesoğlu, 1986: 286).

Kur'an'da çeşitli ayetlerde kuşlardan söz edilmekte ve kuşların havada durmasından insanların ibret almasından bahsedilmektedir (Özek, Karaman, Turgut, Çağırıcı, Dönmez, Gümüş, 2008: 10, 20, 27, 41, 159, 304, 345, 369, 370, 445, 564, 624). Ortadoğu İslam Edebiyatı'nda kuşlar arasındaki konuşmalara dayanan alegorik eserlerin başında Feridüddin Attar'ın Mantık-al Tayr'ı gelmektedir (Akalın, 1993:17). Klasik Türk şiirinde yaygın olan kuş ilgisi Kur'an'dan ve adı geçen eserden kaynaklanmaktadır (Savran, Tıraş, 2017: 46). İslam sonrası Türk Edebiyatı'nda velilerin kuşların şekillerine girerek seyahat etmeleri kuşun dinî ve edebî kültür ortamında edindiği yeri açıkça göstermektedir. Bunun yanı sıra Osmanlı'da kuşçuluk yaygın bir meslek olarak toplumsal hayatın bir parçası olmuş ve padişahın av kuşlarını beslemek için özel görevlileri bulunmuştur (Ceylan, 2003: 233-234).

Klasik Türk şiirinin son devresinin en önemli temsilcilerinden biri olan Şeyh Gâlib’in Hüsn ü Aşk adlı mesnevisinde de kuşlar çeşitli anlam bağlantıları içerisinde yer almış ve Sebk-i Hindî akımının önemli ve başarılı bir temsilcisi olan şairin eserinde sıradışı benzetmelere konu olmuştur. Şiirde yeni bir yol açma ve sıklıkla kullanılmış benzetme ve mazmunlara itibar etmeme isteğini eserinde açıkça dile getiren şair (Doğan, 2015: 64,194) bu arzusunu kuşları işleyiş biçiminde de göstermiştir. Çalışmada mesnevideki kuşlar tespit edilerek bunların gelenekle bağlantıları irdelenmiş ve farklılıklar tespit edilmek suretiyle Gâlib’in şairliği ve eserinin mahiyeti hakkında bir fikir elde edilmeye çalışılmıştır. 
Açılanan beyitler yanlarına numaraları yazılarak belirtilmiş; diğerlerinin ise yalnızca beyit numaraları verilmiştir.

\section{Şeyh Gâlib'in Hüsn ü Aşk'inda kuşlar}

Kuşlar, İslamiyet’ten önceki devirlerden beri Türk toplumunda önemli bir yer tutmuş, Türk kültürü, sanatı, etnografyası ve folklorunda her zaman yer almıştır (Ülgen, 1994: 55). Kuşların Osmanlı şiirine yansıyışları yalnızca birtakım erdemleri temsil eden mesnevi ve latîfe kahramanları olmakla kalmamış, gazeller, kasideler ve diğer nazım şekilleri içerisinde de değişik vesilelerle çok sayıda kuş adı anılmıştır. Bu manzumelerin hemen tamamında, herhangi bir kuş mânâ sanatları aracılığıyla söz konusu edilirken, anılan kuşun fizyolojik ve anatomik özellikleri hakkında halk inanışları ya da mitolojik ayrıntılardan benzetme yönü olarak yararlanılır (Ceylan, 2015: 18). Türk kültüründen etkilendiği kadar Fars ve Arap kültüründen de etkilenen divan edebiyatında, kuş herhangi bir türü belirtilmediğinde genelde tayr (arp.) ve mürg (fr.) şeklindeki karşlıklarıyla kullanılmıştır. Bu kullanımların şairin anlam ve anlatım zenginliğine ulaşmaya çalışması kadar anlatımı kolaylaştırdığı için tercih sebebi olduğu yorumu yapılabilir. "Divan şairi, kendisine geleneğin getirdiği hazır unsur ve malzemeden hareket etmek durumundadır. Belirli konular ve duygular etrafındaki bu hazır unsurlar divan şiirinin değişmez motiflerini meydana getirir" (Akün 1994: 421). Kuşlar, divân edebiyatında "mazmun" denilen hazır unsurlar bağlamında kullanıldığında, verilmek istenen mesaj ve aktarılmak istenen duygular açısından kolaylık sağlar (Akın, Akın, Ayverdi, 2016:83).

Şeyh Galib, Hüsn ü Aşk'ın Der Beyân-ı Sebeb-i Te’lif bölümünde şair Nâbî̀yi eleştirirken kuş mazmunundan yararlanır.

Hem bir dahi var ki ol sühan-sâz

İğrâkda mürg-i pest-pervâz

(Ancak, şurası da var ki, o söz ustası(!) aşırı mübalağalar yapma hususunda alçaktan uçan bir kuş gibidir.)

Eserde murg kelimesinin farklı kullanımlardan birine de Der Vasf-ı Aşk (Aşk'ı Anlatış) başlığı altında rastlarız. Beyitte, Aşk'ın mağrur bakışı doğan kuşuna; Cebrail ise doğanın pençesinde bulunan ve ölmek üzere olan bir kuşa benzetilmektedir.

Mağrûr nigâhına ne kâbil

Cibrîl ola mürg-i nîm-bismil

(Mağrur bakışına, Cebrail’in bile yarı boğazlanmış kuş olması mümkün değil.)

Hüsn ü Aşk mesnevisinde hem fiziksel özellikleri hem de benzetilen olmaları yönüyle birçok kuşun adı geçer. Mesnevide adı geçen kuşlar şunlardır: Anka, bûm (baykuş), bülbül, dürrâc(turaç kuşu), fahte (üveyik), güncişk (serçe), huffâş (yarasa), hüdhüd (ibibik), hümâ, kaknüs, kaz, kebk (keklik), kebûter (güvercin), küleng (turna), mâkiyân (tavuk), nesr ve ukâb (kartal), şâhin, şehbâz (doğan), tâvûs, tezerv (sülün), tîhû (çil kuşu), tûtî (papağan).

Hüsn ü Aşk’ın Der Vasf-ı Aşk (Aşk'ı Anlatış) bölümünde “murg-ı îmân” (500) tamlaması dikkat çekicidir. Şair, Aşk'ın atının terkisine iman kuşunun bir av gibi bağlı olduğu hayalini kurar. Âşıkları, ona kavuşabilmek adına zünnare benzeyen can ipliklerini paramparça etmişlerdir. Zünnar, Hristiyan din adamlarının bellerine bağladıkları kuşağın adıdır. Akaid kitaplarında zünnar kuşanmak küfür alameti 
olarak görülmüştür. Beyite göre Aşk, güzelliği, nazlanması ve âşılara eziyet ediciliği sebebi ile zâlimlik ve kâfirlik ile tavsif edilmiştir.

Çün kıldı hevâ rutûbetin sâz

Göstermedi mürg-ı şu'le pervâz （599)

( Hava nemini iyice arttırdığı için alev kuşu kanat çırpamaz oldu. )

Der Vasf-ı Bahâr (Baharı Anlatış) bölümünde geçen bu beyitte, şair, alevi kuşa benzetmektedir. Havanın rutubetinin artması ile alevin sönmesi alev kuşunun kanat çırpmaması şeklinde yorumlanabilir. Bilindiği üzre kanatları ıslanan kuşlar uçamazlar. Metinde adı açıkça zikredilmese de alev kuşu tabiriyle kendi şevkiyle tutuşturduğu ateşler içerisinde yanarak can veren kaknüs kastedilmiştir. Bir sonraki beyitte şair hayalini bir adım daha ileriye götürerek gülün rengi ve kokusunu somutlaştırmak suretiyle kuşa benzetir.

Sebk-i Hindî şairi Galib’in murg kelimesiyle ilgili farklı hayallerinden biri de Der Vasf-ı Tî̆̆ (Kılıç hakkında) adlı bölümdedir.

Çekmiş anı vâye-bahş-ı ma'den

Murg-1 melekût beyzâsından ～(1474)

(Lütuflar ve kısmetler dağıtan maden ocağı, onu melekût âleminin yumurtasından çıkarmış. )

Beyitte maden ocağı, doğumu gerçekleştiren, çocuğa bakan, besleyen bir dadıya benzetilmiştir. Doğan'a göre bu dadı, kılıç kuşunu melekût âleminin kuşunun -hüma olmalı- yumurtasından doğumunu sağlamıştır. Kılıç, meekût (gökyüzü) âlemine ait kuş diye nitelendirilerek, demirin gökten indirildiğini ifade eden Hadid suresi 25. ayete telmihte bulunulmuştur (Doğan, 2017: 341). Kılıcın sıfatlarını anlatmaya devam eden şair, 1476. beyitte kılıcı kanatlarında kızıl ölüm gizlenmiş, kara haberler getiren bir yeşil kuşa benzetir.

Murg kelimesi metinde birkaç yerde daha kullanılmıştır. Mânâ Mesiresi’nin anlatıldı̆̆ı bölümde güneş, sabah aydınlığında bitmiş bir ağaca benzetilmiş ve bu ağacın üzerinde de ruh kuşları (murg-ı ervâh) yuvalanmıştır (642). Sühan, aşk ve Gayret’i düştükleri kuyudan çıkardıktan sonra bir kuş olup (1320) Hüsn'ün diyarına uçmuştur. Gam harabelerindeki gece ve kışın şiddetinin anlatıldığı bölümde kor ateşten taşların uçuştuğu mekânda havada tek bir kuşun bile kalmadığı belirtilmiştir (1346).

Murg kelimesi, yukarıda örnek olarak verilen beyitlerin dışında, 601, 1320, 1914 numaralı beyitlerde kullanılmıştır. 1342. ve 1467. beyitlerde kuş mazmunu bulunmaktadır.

\section{Ankâ}

Uzun boylu dev, gerdanlık, gerdanlık takmak ve boğmak anlamlarına gelen İbranice kökenli bir isim olan Ankâ, ismi olup da cismi olmayan büyük bir kuştur (Ceylan, 2015: 31; Onay, 1996: 102). Ankâ, dünyanın zirvesi ve Allah'a yakınlık makamı olan Kaf'da yaşadığı ve yükseklerde uçtuğu için yüceliğin, ululuğun da sembolüdür (Güler, 2014: 71). Yere konmaması, kanadının nakışları, yaşadığı yerin tam olarak bilinmeyişi, küllerinden yeniden ortaya çıkması, köşk benzeri yuvası, hiçbir şekilde insanlar tarafından avlanamaması, cennet kuşu oluşu ve bazen yeşil olarak kabul edilen rengi ile çeşitli teşbih ve mecazlara konu olur. 
Bâl ü peri sebz nûr-ı hadrâ

Gûyâ ki o kûh-ı Kâfa ankâ

(1932)

(Kapıların kanatları yemyeşil, siyah nur... Sanki o Kaf Dağı’nın Anka kuşları...)

Şeyh Gâlib Hüsn ü Aşk’ta, Der Zikr-i Resîden-i Aşk Be-Hisâr-ı Kalb ve Garâib-i Ân (Aşk’ın Kalp Kalesine Varışı ve Oradaki Acayiplikler Hakkında) adlı bölümde, Kalp kalesini yücelik ve ihtişam yönüyle Kaf Dağı’na, kalenin koyu yeşil kapılarını da Kaf Dağı'nın Ankâ kuşlarına benzetmektedir.

Şehname'deki kullanımından da yararlanılarak hayal çerçevesi genişletilen Ankâ; kırmızı ve altın rengindeki tüylere sahipse, renk açısından, ateşle arasında bağlantı kurulur. Eserde Aşk ile birlikte ateş denizine giren ve kırmızı renkte olan Aşkar ile Ankâ arasında renk ve uçuş şekli yönünden bir ilişki vardır.

Aşkar süzülüp misâl-i ankâ

Ol âteşe gitdi bî-muhâba

(Aşkar, Anka kuşu gibi süzülüp hiç tereddüt etmeden bu ateşe daldı.)

Ankâ (Simurg) tasavvufta ve tasavvufî Türk edebiyatında Attâr'ın Mantıku’t Tayr ile Nevâînin Lisânü't Tayr'ında mülhem olarak vahdet-i vücûd düşüncesi içerisinde adem-i mutlak'in sembolüdür. Simurg otuz kuş olarak ele alınınca çokluğu ifade eder oysa varlığın birden çok olması vehmi ve hayalidir. Anka gibi çokluğun da gerçekte adı ve kendisi yoktur diğer taraftan simurg kuşların tek padişah olması dolayısıyla birliği ve gerçek varlığı yani Allah“e i ifade eder. Aynı zamanda heyûlâya ve hebâ'ya anka denir. Çünkü heyûlâ anka gibi suret olmadan ne görülür ne de mevcut olur sadece mahlûktur (Ceylan, 2015: 33).

Şair, metinde eski kimya ilmi ile Ankâ’nın görünmezliği ve cisimsizliği arasında ilişki kurar.

Kim vardı diyâr-ı kimyâya

Ankâya erişdi ya hümâya

((Yoksa), kimya ülkesine kim varabildi! Kim Anka'ya ve hümaya erişebildi!)

Ankâ, söz sanatlarında kullanılan fiziki özelliklerinin yanı sıra pek çok soyut değer ile de bağdaştırılır. Bunlar; adem, hakikat, hayal, himmet, mânâ, kerem, lütuf, ihsan, erdem, vefa gibi pek çok mücerret kavramla ilişkilendirilir. Ankâ kuşu, çok geniş bilgi ve hünerlere sahiptir; kendisine başvuran hükümdar ve kahramanlara akıl hocalı̆̆ı yapar. Hz. Süleyman'ın meclisinde bulunmuştur (Akın, Akın, Ayverdi, 2016: 87). Eserin Der Vasf-ı Esb (At Hakkında) bölümünde Aşkar, sözden anlayan uçarken büyülü bir alevi andıran Ankâ kuşuna benzetilmiştir.

Ankâ-yı sühân-şinâs-ı hoş-dem

Pervâzda şu'le-i mutalsam

(Hoş nefesli, sözden anlayan bir Ankâ kuşu; uçuşta, büyülü bir alev...)

\section{Bûm (Baykuş)}

Divan şiirinde bûm ve cuğd adları ile geçen baykuş, uğursuzluğu ve insanlara verdiği zararla bahtı ve dünyayı temsil eder. Baykuşun uğursuzluk getirdiğine dair olan halk inancı dolayısıyla, insanlar ve diğer kuşlarca dışlandığı kabul edilir. Kasvetli ve itici çağrışımlarıyla ağyar ile servet düşkünü zahidi akla getirir. Âciz kuşların yumurtalarına ve yiyeceklerine de musallat olmaları bakımından da açgözlü zenginleri anımsatırlar. (Akın ve diğerleri, 2016: 95). 
Aşk, tema olarak mesnevinin ana motifini teşkil etse de tema, kendisiyle birlikte her zaman için iki gücü taşır: Anlatının kendi içindeki olumlu seyir olan tematik güç ve anlatının olumsuz seyri, karşı güçç (İçi, 2010: 60). Bu çatışma eserin tamamında görülse de Muhabbetoğulları'nı tasvir eden bölümlerde yoğunluğunu çok fazla hissettirir. Metinde baykuşun ilk defa zikredildiği Sifât-ı Şikâr-ı Îşân (Avlanmalarının Tarifi) bölümünde çizilen tablo, zıtlıklar üzerine kurulmuştur. Bahsedilen varlıklar, sahip oldukları vasıflarının zıttıyla tavsif edilmişlerdir. Beyitte, doğanların alıcılıkları ile hasret bakışı; av ile korku baykuşu arasında bir ilişki bulunmaktadır. Burada korku baykuşu ifadesi ilginçtir. Baykuş gece avlanan bir kuştur fakat gündüz olunca gözleri görmediği için av olur. Muhabbetoğulları kabilesinin doğana benzeyen bakışlarla korku baykuşları avlaması şairin, renkli ve farklı hayal dünyasının tezahürüdür.

Şehbâzları nigâh-ı hasret

Dutdukları cuğd u bûm-ı dehşet （265)

(Alıcı doğanları, hasret bakışıydı; tuttukları ise korku baykuşları...)

Baykuş, mesnevide iki yerde gurbet baykuşu olarak nitelendirilir. Revân-ı Şüden-i Aşk Be Harâbe-i Gam (Aşk'ın Gam Harabelerine Gidişi) bölümünde Hüsn'den ayrı düşen Aşk ve yurdundan çok uzaklarda bulunan Gayret için gurbet baykuşu sıfatı kullanılır (1322. beyit).

Âgâhî Dâden-i Sühan Be-Sûret-i Tezerv (Sühan'ın Sülün Kıllğına Girerek Haber Getirmesi) bölümünde Aşk, bir gurbet baykuşudur ve onun için sevgilinin olmadığı her yer bir baykuş yuvasıdır. Ceylan'a göre, baykuş türünden bir kuş olarak kabul edilen, geceleri acı acı öten ishak kuşu, Türk folklorunda birbirlerinden ayrı düşmüş yeni evli iki genci temsil eder (Ceylan 2015: 52).

Kaldı o gül-i harîm-i vuslat

Ol bâğda hemçü bûm-ı gurbet (1691)

(Vuslat hareminin gülü (Aşk) o bahçede gurbet baykuşu gibi kalakalmıştı.)

Mesnevide baykuşla ilgili en ilgi çekici sıfat, harabeden nefret eden baykuş ifadesidir. Divan şairlerinin baykuş hakkındaki ilk ve umumi kanaatleri onun uğursuzluğu ve bu yüzden insanlar ve diğer kuşlarca tecrit edildiği yolundadır. Şom (şûm) kabul edilen baykuş, uğursuzluğu ve insanlara verdiği zararla bahtı ve dünyayı hatırlatır. (Ceylan, 2015: 53) Baykuşun yaşadı̆̆ı yerin viraneler olması şairler için değişik hayallere zemin hazırlar. Galib bu beyitte gönlü viraneye, uğursuz talihi de baykuşa benzetmiştir.

Oldı dile şûm düşmen

Vîrâneyi gör ki bûm-düşmen (1786)

(Uğursuz talih, harabeden nefret eden bir baykuş gibi gönlüme düşman oldu.)

\section{Bülbül}

Divan edebiyatının gözdesi, şiirimizin âşık kuşu olarak kabul edilen bülbülün çiçeklere ve güle olan düşkünlüğü onu karşılıksız ve riyâsız aşkın bir timsâli kılmıştır (Ceylan, 2015: 64). Doğu edebiyatlarında önemli bir yeri olan bülbül güllerin açtığı günlerde daha canlı öttüğünden gül ile arasında muhayyel bir aşk ilişkisinin var olduğu kabul edilmiş, bülbül âşı̆̆a, gül de mâşuk veya mâş̧ukaya benzetilmiştir (Kurnaz, 1992: 485-486).

Şeyh Gâlib, Hüsn ü Aşk’ta işlenen aşkın sıradan aşklar gibi olmadığını belirtmek için kuşları alışılmışın dışında hayallerle kullanmıştır. Sebek-daş Şüden-i Îşân Der mekteb-i Edeb (Edep Mektebinde Sınıf 
Arkadaşı Oluşları) bölümünde Hüsn ve Aşk'ın birbirlerine olan muhabbetinden bahsederken onları birbirlerine bülbül olan iki gül olarak nitelendirmiş, mâşuk kadar kusursuz iki âşık olduklarını okuyucuya işaret etmiştir:

\author{
Bir şâhda iki gonca-i gül \\ Birbirlerine olurdı bülbül \\ (349) \\ ((Sanki) bir dalda iki gül goncası birbirlerinin bülbülü olmuştu.)
}

Klasik Türk şiirimizin bülbül kadar şöhretli bir diğer âşık benzetmeliği de pervânedir. Pervâne de bülbül gibi çektiği acılar ve göze aldığı fedakarlıklarla tasavvufî ya da beşerî tüm aşk anlatımlarında âşı̆̆ın teşbihi olur. Pervânenin sevgilisi ise gülün bütün özelliklerine sahip olan mumdur (şem'). Şairlerimiz pek çok beyitte bülbül ve pervaneyi karşılaştırırlar. Bu karşılaştırmalarda pervane; sabrı, aşkını gizlemesi ve nihayet kendisini mum alevinde (sevgilisinde) yok etmesiyle bülbüle tercih edilir (Ceylan, 2015: 73).

Mesnevide sıradışı aşk işlenirken pervâne- bülbül (âşık) ve şem- gül (mâşuk) paralelliği de bozulmuş, Âşık Şüden-i Hüsn Bâ Aşk (Hüsn’ün Aşk’a Âşık Olması) bölümünde Hüsn’ün aşkı anlatılırken âşı Hüsn güle ve pervâneye teşbih edilmiştir. Hüsn'ün pervâneye benzetilmesinin sebebi aşkını sevgilisine belli etmeden için için yanması, güle benzetilmesinin sebebi ise gelenekte olması gereken yerin belli edilmek istenmesidir:

Var eyle o gülşeni tahayyül

Pervânesi gül çerâğı bülbül

(Var şimdi pervanesi gül, çerağı bülbül (olan) o gül bahçesini hayal et!)

Bülbül için bahar mevsiminin gelişi büyük aşkı gülün gelişinin habercisidir. Bülbül özellikle bahar mevsiminde gül bahçesine gelerek sevgilisi gül için feryât edip dağı taşı aşkından haberdar etmektedir. Âmeden-i Hüsn Gâh Gâh Be-Halvet-gâh-ı Aşk (Hüsn’ün Arada Bir Yalnızlık Yurduna Gelişi) bölümünde sevgilisi Aşk’ı gizlice ziyaret eden Hüsn içinse durum farklıdır. Hüsn, gece vakti yanına geldiği sevgilisi Aşk’ı uyandırmamak için sessiz feryât eden bir bülbül gibidir:

Ya’nî ki o bülbül-i hôşs-elhân

Hâmûş hâmûş ederdi efgân

(Yani o tath tatlı şakıyan bülbül durmadan sessiz sessiz feryat ediyordu.)

Divan edebiyatının bu pervâsız küçük kuşu için çeşitli özelliklerini belirtmek amacıyla farklı isimler verilmiştir. Sesinin güzelliği dolayısıyla hezâr-destân (bin bir türlü hikâye söyleyen), hoş-hân (güzel okuyan), hoşgû (güzel söyleyen), hoş-âheng (güzel sesli) gibi yakıştırmalar yapılmıştır. Farsça'daki bin anlamına gelen hezâr da bülbülün diğer isimlerinden biridir. Şairler hezâr kelimesinin bu iki anlamını kullanarak şiirlerinde kelime oyunları yapmışlardır. Hüsn ü Aşk şairi de Âvîhten-i Câdû Aşk Râ (Cadının Aşk’ı Asması) bölümünde Aşk’ın yolculuk sırasında çektiği ıstırapları anlatırken bu kelime oyununa başvurmuştur:

Eylerdi hezâr-gûne efgân

Sanırdı gören hezâr-ı nâlân ～(1426)

(Istrrapla öyle haykırıyor, öylesine inliyordu ki; görenler onu ağlayıp inleyen bülbül sanırdı.) 
Mutasavvıf ya da tasavvufa meyyâl şairler, bülbülü daha geniş mânalı bir alegori olarak kullanırlar. Bu istimâle göre bülbül, ilahi aşkla yanan can veya ruhun timsalidir ki, bu dünya veyahut ten kafesinin içinde uzak kaldığı ezeli gül bahçesinin hasreti ile feryât eder (Kaplan, 1979: 833).

Şeyh Gâlib, Hüsn ve Aşk’ı Mânâ Mesiresi adını verdiği seyirlikte dolaştırırken okuyucuya burayı tasvir eder. Gerçek dünyada karşımıza çıkamayacak olan bu bahçe tasavvuru, ideal güzelliğiyle bir cennet bahçesidir. Mânâ Mesiresi'nin çiçeklerinden havuzlarına kadar orada varlık bulan her şey eşi bulunmaz güzelliktedir. Bu mesirenin goncaları bile büyüklüğüyle al kanatlı bülbülleri andırmaktadır:

Hem-hâlet-i gülşen-i tahayyül

Gül-goncalar al kanadlı bülbül

((Orası) hayal gül bahçesi ile aynı güzellikte... (Burada) gül goncaları al kanatl bülbüller gibidir.)

Aşk, Gayret ile birlikte çıktığı Kalp kalesi yolculuğunda Çin sahiline varır. Güzellikte Mânâ Mesiresi'ni andıran bu sahilde de yol, cennet bahçelerini andırmaktadır. Şair, Çin sahilini anlatırken Mânâ Mesiresi'nde olduğu gibi çiçekler ve kuşları birbirlerinin teşbihi olarak kullanmıştır. Orada bülbüllerin kokusu güller kadar güzeldir:

Bir rütbe-i hevâsı sâf ü dil-cû

Bülbülleri gonca gibi hoş-bû

(1613)

(Havası öylesine saf ve gönül çekiciydi ki, bülbülleri bile gül goncaları gibi hoş kokuyordu.)

Ömür Ceylan, Kuşlar Divanı adlı eserinde, Türk dünyasında anlatılan menkıbe ve efsanelerde kahramanların çeşitli sebeplerle kuş donuna girdiklerinden bahsetmiş, Horasan erenleri başta olmak üzere bazı velilerin kimi kuşların şekline girerek seyahat ettiklerini (Hoca Ahmet Yesevî: turna, Hacı Bektâş-1 Velî: güvercin) belirtmiştir (Ceylan, 2015: 7). Hüsn ü Aşk'ın çeşitli bölümlerinde de bu örneğe rastlanmaktadır. Hüsn ve Aşk’ın bütün müşkülünü çözüp, iyi ve kötü günlerinde daima yanlarında olması ve gâipten haber vermesi gibi özellikleriyle Dede Korkut'u çağrıştıran Sühan (Tanç, 2013: 2355) Cemal Kurnaz'a göre de ilahî aşka ulaşmak isteyen kişiye yardımcı olan mürşidi temsil eder" (Kurnaz, 2004: 341). Sühan'ın papağan, sülün ve bülbül kılığına girerek Aşk’a yardımcı olmasını onun bir mürşid olarak hikâyede yer almasıyla açıllamak mümkündür.

Hikâyede üç yerde rastlanılan bu motif Âgâhî Dâden’i Sühan Be Sûret-i Bülbül (Sühan'ın Bülbül Kılığına Girerek Haber Vermesi) bölümünde şu şekilde görülmüştür:

Nâlân olarak gezerken ol mâh

Bir bülbül-i mest gördi nâgâh （1757)

(O ay yüzlü (Aşk) inleyerek dolaşırken birdenbire mest olmuş bir bülbüle rastladı.)

Kim Aşka hitâb edip o bülbül

Zencir-i gama verir teselsül

(O bülbül, Aşk’a seslenerek gam zincirinin halkalarına (şöylece) yeni halkalar eklemeye başladı: )

Bülbül, yukarıdaki beyitlerin dışında 147, 174, 280, 621, 829, 945, 946, 950, 1606,1670, 1814, 1995 numaralı beyitler ve Tardiyye IV (s. 370) Tardiyye VI (s. 372) ‘da geçmektedir. 


\section{Dürrâc (Turaç Kuşu)}

Turaç kuşu, keklikgillerden fakat keklikten biraz irice, sülüne benzer güzel ve sevilen bir av kuşudur. Şiirimizde sesinin güzelliği ve etinin lezzeti ile ele alınır. Şair, Sıfât-ı Şikâr-ı Îşân (Avlanmalarının Tarifi) bölümünde Muhabbetoğulları'nın avlanmaya niyet ettiklerinde turaç kuşunun kanatlı akrebe döndüğünü söylemektedir. Bu öyle bir kabiledir ki yaptıkları, yaşadıkları her şey olağandışıdır.

Tîhûları sûsmâr olur hep

Dürrâcları perende akrep （264）

((Orada) çil kuşları hep kertenkeleye döner, keklikleri bütün kanatl akrep olurdu. )

Gâlib, Der Vasf-ı Ân Nüzhetgâh (Mânâ Mesiresi Hakkında) başlığı altında Mânâ Mesiresi’ni tasvir ettiği bölümde keklik ve turaç kuşlarını periden askerler olarak tavsif eder. Bu kuşlar kendilerini iyi gizledikleri ve güzel olmaları hasebiyle periye benzerler.

Hüdhüdleri serde Cem gibi tâc

Perrî çerîsiydi kebk ü dürrâc

(Hüthütleri, Süleyman peygamber gibi başlarında taç taşıyorlardı; keklik ve turaç kuşu sürüleri de oranin periden askerleriydi.)

\section{Fâhte (Üveyik)}

Üveyik kuşu, yabani bir güvercin türüdür. Endamının güzelliği, sesinin hoşluğu, onu şaire malzeme yapar. (Onay 1992: 162). Eserde fâhte tek bir beyitte geçer. O da "Der Sifat-ı Şeb ve Şiddet-i Şitâ" (Gece ve Kışın Şiddeti Hakkında) bölümündedir:

Nesr-i felegi görüp kümesde

Kesdi sesi fâhte kafesde

(1361)

(Üveyik kuşu, gökyüzü kartalının kümeste (kapal) olduğunu görünce sesini çıkarmaz oldu.)

Metinde geçen "nesr-i felek" gökyüzü kartalı anlamındadır. Üveyik, keklik gibi av kuşları, kartal, şahin, akbaba gibi vahşi ve yırtıcı kuşları gördüklerinde korku ile çığlıklar atıp sağa sola kaçışırlar. Üveyik, gökyüzü kartalının kafeste kapalı olduğunu anlayınca artık rahatlamış ve sesini kesmiştir. Doğan’a göre, beyitte tevriye yolu ile güneş veya batı (nesr-i tâir) ve doğudaki (nesr-i vâki) parlak yıldızlar, kafeste hapsolmuş kartala benzetilmektedir. Kışın havanın kapalı oluşu sebebiyle güneşin ve yıldızların görünmemesi şairde böyle bir çağrışım uyandırmıştır (Doğan, 2017: 315).

\section{Güncişk (Serçe)}

Şiirimizde cüssesi itibariyle acizliği, muhtaçlı̆̆ı ve önemsizliği simgeler. Şairlerimiz daha çok bir başka kuşun özelliğini vurgulamaya çalıştıklarında serçeyi mukayese unsuru olarak kullanırlar (Ceylan, 2015: 218). Serçe (Güncişk) metinde "Der Sıfat-ı Şeb ve Şiddet-i Şitâ" (Gece ve Kışın Şiddeti Hakkında) bölümünde kış mevsiminde oynanan bir çocuk oyunu vesilesiyle geçer.

Tâ olmaya dâne-çîn-i hirmân

Güncişke şerer dökerdi sıbyân (1362)

(Çocuklar serçeler yemsiz kalmasın diye önlerine kıvılcım dökerlerdi.) 
Kışın yanan sobaların kıvılcımlı külleri karın üzerine serpildiğinde, kızgın kül zerreleri karı eriterek toprağa saçılmış buğday tanelerinin manzarasına benzer bir görüntü ortaya çıkar ve böylelikle kar üzerindeki bu şekilleri yem sanarak gelen kuşlar, gerçek yem yerine mahrumiyet, aldanma ve nasipsizlik yemi toplamış olurlar. Bunun yanında, kara ikliminde olup kışların uzun ve soğuk yaşandığı yörelerde çocukların en ilginç oyunlarından birisi de karların üzerine işeyerek tıpkı kıvılcım tanelerinin kar üzerinde çizdiği yem manzarasına benzer şekiller oluşturmalarıdır. Şair, "şerer" kelimesini esprili bir şekilde kullanmak sureti ile bu ilginç çocuk oyunundan okuyucuyu haberdar etmektedir (Doğan, 2017: 317).

\section{Huffâş (Yarasa)}

Yarasa şiirimizde ışıktan rahatsız olması ve güneşin ilk ışıklarıyla hareket kabiliyetini kaybetmesi yönüyle kullanılır. Geceleri ürkütücü ve iç burkucu ötüşü de şairlerimizin sık sık andıkları bir özelliğidir (Ceylan, 2015: 244).

Âmeden-i Hüsn Gâh Gâh Be-Halvet-gâh-ı Aşk ( Hüsn'ün Arada Bir Aşk'ın Yalnızlık Yurduna Gelişi) başlığı altında Hüsn geceleri dolaşması sebebiyle yarasaya benzetilmiştir. Hüsn, Aşk’a âşıktı, ama nazı niyazından çok olduğu için onu geceleyin seyretmeyi yeğ tutmuştu. Hüsn'ün bu vaziyeti, Yusufu Züleyha kıssasını hatırlatan geleneksel aşk hikâyelerinde âşı ile maşuk ilişkisini, tersine çeviren bir özelliğe bürünmüştür (Bingöl, 2013: 216). Aynı beyitte Hüsn'ün aslında bir hüma olarak nitelendirilip akabinde yarasa olarak vasıflandırılması, aynı karaktere iki zıt özelliğin atfedilmesi dikkat çekicidir.

Huffâş-veş ol hümâ-yı devlet

Şeb-revligi eylemişdi âdet

(O, devlet kuşu yarasa gibi geceleri dolaşmayı adet edinmişti. )

\section{Hüdhüd (İbibik)}

İpek kuşu, çavuşkuşu, ibibik adıyla bilinen Hüdhüd, divan şiirinde Hz. Süleyman'ın haberci kuşu olması, başındaki taca benzeyen ibiğiyle kullanılır. Hüdhüd’ün divan şiiri kuş kadrosu içerisinde kendisini diğer kuşlardan ayıran en önemli fizyolojik özelliği başındaki ibiğidir. Herhangi bir yere konduğunda bir yelpaze gibi açtığı ibiği, aynı zamanda Hz. Süleyman'ı çağrıştırır şekilde saltanat tacı ile özdeşleştirilir.

Hüdhüdleri serde Cem gibi tâc

Perrî çerîsiydi kebk ü dürrâc (672)

(Hüthütleri, Süleyman peygamber gibi başlarında taç taşıyorlardl; keklik ve turaç kuşu sürüleri de oranin periden askerleriydi.)

Metinde geçen Cem, Hz. Süleyman'ı işaret etmektedir. Çünkü cinler ve periler Hz. Süleyman'ın emrinde asker olarak görev yapıyorlardı (Doğan, 2017: 171).

Kim böyle kuruldı tâ bu dîvân

Muhtâc idi hüdhüde Süleymân

(Çünkü bu dünya divanı böyle kuruldu; Hz. Süleyman bile hüthüt kuşuna muhtaç olmuştu.)

Hikâyeye göre, insanların cinlerin, hayvanların ve rüzgarın padişahı olan Hz. Süleyman su bulması için Hüdhüd’ü keşfe gönderir. Çünkü Hüdhüd çok keskin bir görüşe sahiptir. Yer altında bulunan suyu insanın bardakta gördüğü gibi görür. Yemen civarına ulaşan Hüdhüd, Seba Melikesi Belkıs’ın saltanatını görür ve su arama görevinden feragat ederek Belkıs'n ülkesini dolaşır. Bu kayboluşa kızan Hz. Süleyman, onu bulması için karakuşu/akbabayı görevlendirir. Hüdhüd bulunur ve huzura getirilir. 
Belkıs ve ülkesinden bahsedince affedilir. Güneşe tapan Belkıs ve halkına davetname gönderilir. Bu davete icabet eden Belkıs, Hz. Süleyman'ın dinine girer ve onun eşi olur (Ceylan, 2015: 127). Her padişah saltanatını başka diyarlara ulaştırmak için elçiye ihtiyacı vardır. Hz. Süleyman için bu elçi Hüdhüd'dür.

Aldı Sühan azm-i râh kıldı

Hüdhüd gibi kasd-ı şâh kıldı

(915)

(Sühan onu (mektubu) alarak yola koyuldu. Hüdhüd kuşu gibi sultana yöneldi.)

Âverden-i Sühan Nâmerâ Ber Aşk (Sühan'ın Mektubu Aşk’a Ulaştırması) başlığı altında Sühan Hüdhüd ile eş tutulmuştur. Biri Hz. Süleyman'ın posta kuşu, diğeri ise iki âşı̆̆ın habercisidir. Hem genç hem çok zeki bir ihtiyar olan Sühan; yüce bir kişiliğe sahiptir ve sanki dünyadan daha yaşlıdır. Güzelliğin ve aşkın anlamını bilen Sühan'ın düşüncesi, karanlığı aydınlatan bilgi ışığı gibidir (Bingöl, 2013: 223). Hüsn’ün mektubunu Aşk’a Sühan götürür ve Aşk’ın mektubunu Hüsn'e getirir.

\section{Hümâ}

Arapçası bulah, Farsçası hümâdır. Devlet kuşu demektir (Onay, 1996: 276). Baht, talih, kutluluk, saadet, kudret gibi pek çok anlamı karşılayan ve sıfat görevinde terkipler yapan hümâ; masalımsı özellikleri sebebiyle daha fazla hayale zemin hazırladığından şiirin mânâ zenginliğini arttırır. Sadece yırtıcı kuşları avlayıp diğerlerini incitmeyen şerefli bir kuş olduğuna da inanılan hümâ; ayaksız olduğu ve hiç ele geçmediği düşüncesinden dolayı edebiyatımızda refah, kudret ve mutluluğa giden baht olarak kabul edilir (Akın ve diğerleri, 2016: 86). Eskiden bir meydandan hümâ uçurulur ve kimin başına konarsa o kişi padişah olurmuş. Bu bakımdan hümâ bir devlet kuşu olarak bilinir.

Huffâş-veş ol hümâ-yı devlet

Şeb-revligi eylemişdi âdet

(O, devlet kuşu yarasa gibi geceleri dolaşmayı adet edinmişti.)

Âmeden-i Hüsn Gâh Gâh Be-Halvet-gâh-ı Aşk (Hüsn'ün Arada Bir Aşk’ın Yalnızlık Yurduna Gelişi) başlı̆̆ı altında Hüsn, devlet ve kut kuşu kabul edilen hümaya benzetilir.

Nesr-i felek indi âşiyâna

Gül-gonca hümâya oldı lâne

(604)

(Kartal, (gökyüzünden inip) yeryüzünde yuvalandı; gül goncası da Hüma kuşuna yuva oldu.)

Şair, Der Vasf-ı Bahâr (Bahar Hakkında) bölümünde yer alan beyitte, yeryüzünün baharın gelmesiyle birlikte yeşillenip çiçeklerle süslendiğini, gökyüzünden daha güzel bir hale büründüğünü, hep göklerde bulunan ve gölgesi dahi yeryüzüne düşmeyen Hüma kuşunun bu güzelliğe kayıtsız kalamadığını söyler. Hatta bu durumu mübalağa yaparak yuvasını gül goncasının içine yaptığını belirtir.

Hümâ kuşu yukarıdaki beyitler dışında 1283 ve 1322 numaralı beyitlerde de kullanılmıştır.

\section{Kaknüs}

Kaknüs; Türkçedeki kullanımıyla kuğu, güzelliği ve musikiyle alakası ile bilinir. Dünya mitolojilerinde güzellik sembolüdür. Divan edebiyatında pek çok ismi bulunmaktadır; en çok kullanılanlardan biri de musîkârdır. Musîkâr, "Hind adalarında yaşayan, kanatları nakışlı, gagası deliklik mevhûm bir kuş. Yüzünde 360 deliği varmış. Yüksek dağ başlarında rüzgâra karşı oturunca rüzgâr o deliklere nüfuz eder, 
muhtelif sesler çlkarırmış. Bu sesi işiten kuşlar yanına üşerlermiş, onlardan birkaçını yermiş.” (Onay, 1996: 299).

Bu efsanevi kuşun bin yıl yaşadığı rivayet edilir. Bin yıl dolduğunda pek çok odun ve çalı çırpı yığıp üzerine çıkarak içli içli ötmeye başlarmış. Bir süre sonra ötüşüyle cezbeye gelip kanatlarını çırpar ve odunları tutuşturarak yanıp kül olurmuş. Külleri arasında bir yumurta ve o yumurtadan yeni bir kaknüs çıkarmış. Mûsıkînin, gagasındaki deliklerden çıkan melodilerden esinlenerek icat edildiğine inanilır (Ceylan, 2015: 134- 135).

Güzelliği, musikiyle olan alakası ve hazin bir sonla biten hikâyesinden ötürü şiirimizde güzel, zarif kullanımlar doğurmuştur. Kimi zaman aşığın gönlü, yahut aşı̆̆ın ta kendisi olmuş, kimi zaman çeşitli teşbihlerle güneşe benzetilmiştir. Müzikle ilgili kullanımlarında genelde musîkâr ismiyle anılmıştır. Fakat ateşli, dumanlı hikâyesi olan bu güzel, efsanevi kuş, Şeyh Gâlib’in hayal dünyasında bambaşka bir kalıba bürünmüştür. Mesnevinin Mebâhis-i Diğer (Diğer Konular) bölümünde Gâlib; birtakım şair gruplarından bahseder. Yeni mazmunun olmadığını iddia eden ve şairlerin yalnızca hırsızlık yaparak şiir yazabileceğini söyleyen kahvehane şairleri Gâlib’e göre “ateşler, dumanlar içinde pinekleyip boş sözler yumurtlayan kaknüs kuşu”ndan farksızdır.

Şairin bu kaknüs benzetmesi mesnevide en dikkat çeken kuş teşbihlerinden biridir; çünkü şair, gelenekte olumlu kullanılan kuşu olumsuz olarak kullanmakla kalmamış, efsanevi bir kuş olan kaknüsün doğal olarak soyut kullanıldı̆̆ı şiir geleneğinde kaknüsü kahvehanenin içinde bir şair olarak somutlaştırmıştır:

Ammâ ki biraz da yâve-sencân /Pes-mânde-i kavm-i cân bin cân

Zu’minca sühan-ver-i zemâne / Seccâde-nişîn-i kahvehâne

Tiryâkî-i herze-hâb-ı menhûs/ Âteşler içinde hemçü kaknûs

Birbirlerine edip tekâpû/ Derler ki efendi böyledir bu （714- 717）

(Ama kahve köşelerinde ateşler, dumanlar içinde kaknüs kuşu gibi pinekleyerek sayıklayan ve boş sözler yumurtlayıp kendilerini zamanın en büyük söz ustası sanan birkaç aşağllı cin oğlu cin de birbirlerine dalkavukluk yaparak şöyle diyorlar... )

\section{Kaz}

Kaz; ördekgiller familyasından, gri ve beyaz tüylü, bitkiyle beslenen, bâzı türleri göçebe olan, bâzı türleri ise kümes hayvanı olarak yetiştirilen, perde ayaklı büyük kuş cinsidir. Şiirlerde su kuşu ve av kuşu olmasıyla yer almıştır. Özellikle yaban kazının saflık ve ahmaklık kinayesi olarak şiirlere girdiğgini görmekteyiz (Ceylan, 2015: 158). Gâlib, Sebeb-i Telif bölümünde Nâbî’nin Hayrâbâd adlı mesnevisini eleştirirken kazı bir mukayese unsuru olarak kullanmıştır:

Olsa ne kadar şikeste-pervâz

Uymaz yine kûf u kaza şehbâz

(Ne kadar kanadı kırık da olsa, şahin yine de baykuş ve kaz ile bir olmaz.)

\section{Kebk (Keklik)}

Divan şiirinde kebk adıyla kullanılan keklik; sülüngiller familyasından, avlanması zor olan eti lezzetli bir av kuşudur. Sekerek yürüyüşü, av kuşu olması, güzelliği ve anne kekliğin tehlike anında yavrularını dağıtarak kendini öne atması şiirlerde işlenmiştir. Kekliğin zarif yürüyüşü onun hoş-reftâr, hoş-hırâm gibi sıfatlarla anılmasını sağlamıştır. Bu yönüyle salınan serviler gibi sevgilinin benzetmeliğidir (Ceylan, 
2015: 162). Şair, Miyânci Keşten-i Sühan Der Miyân-ı Îşân (Sühan'ın Onlara Aracı Olması) bölümünde hem âşık hem mâşuk olarak karşımıza çıkan Hüsn'ü sevgilinin sıfatı olan keklikle nitelendirmektedir. Ayrıca divan şiiri geleneğinde av ve avcı olan iki kuşun beyitte birbirlerine âşık iki insan olarak karşımıza çıkması dikkate değerdir:

İkisi de gerçi kim nazar-bâz

Ammâ biri kebk ü biri şehbâz

(Gerçi her ikisi de birbirlerine arzu ile bakıyorlardı ama; biri keklikti, biri şahin.)

Bu kuş, yukarıdaki beyitin dışında 672. beyitte de geçmektedir.

\section{Kebûter (Güvercin)}

Divan şiirinde kebûter ve hamâm adıyla kullanılan güvercin, genelde soluk gri, kahverengi ya da pembe renklidir. Bacakları ve boynu kısa, gövdesi şişman, başı ufaktır (Öner: 2008, 570). Güvercin, divan şiirinin en sevilen kuşlarından biridir. Bunun ilk ve en önemli sebebi şüphesiz güvercini diğer kuşlardan ayıran postacılık özelliğidir. Bazı kaynaklar, Hz. Nuh'un tufandan sonra yeryüzünde yaşanabilecek toprak parçalarının tespiti için bir güvercini üç kez gönderdiği inancından hareketle güvercini insanoğlunun ilk evcilleştirdiği hayvan olarak kabul ederler (Ceylan, 2015: 99,103). Nuh kıssasında yer almasından ötürü dinî mahiyetli göndermelerde fazlaca kullanılır. İslamiyette barışın, sevginin ve masumiyetin sembolüdür.

Kebûter, beyaz rengi sebebiyle masumiyet ve saflık açısından sevgiliyi karşılar. Şeyh Gâlib, Der Vasf-ı Hüsn (Hüsn’ü Anlatış) bölümünde Hüsn'ün fiziksel özelliklerini tasvir ederken güzelliğini ve nâzenîn oluşunu onu güvercine benzeterek vurgulamıştır:

Hayret-dih-i cân o çeşm-i şehbâz

Âhû-yı füsûn kebûter-i nâz (424)

(O, ahıı doğana benzeyen gözü, can (kuşun)u şaşkınlı̆ga düşürürdü; büyüleyiş ceylanıydı, naz güverciniydi.)

\section{Küleng (Turna)}

Leylekten biraz irice göçmen, yerli kuşlardandır. Gri, beyaz, siyah tonlarının karışımı renkleri vardır (Öner, 2008: 561). Boyunlarında bulunan süs tüyleri divan şiirinde sevgilinin yüzündeki "hat"lara benzetilerek kullanılmıştır. Turnalar ağır kanat vuruşları ile sürüler halinde "V" oluşturarak uçarlar. Klasik Türk şiirinde daha çok anıldıkları özellikleri ise gökyüzündeki düzenli uçuş şekilleridir. Uçuş şekilleri sevgilinin bulunduğu yere tam bir teslimiyet ve intizamla giden gönül kuşlarına, âşığın feryatlarına, bulut öbeklerine, hiçbir şekilde şaşmadan ilerleyen aylara, yıllara vb. benzetilir (Ceylan, 2015: 239).

Turna aynı zamanda bir av kuşudur. Şair Gâlib de turnayı bir av kuşu olarak Muhabbetoğulları kabilesinin avlanmalarında kullanır. Fakat bu av sahnesinde her varlık olağandışı sıfatlarla zikredildiği için turnalar, yılanlarla eş değer görülmektedir. Kabilenin avlandığı yer öyle tuhaftır ki, insanlar büyük yılanları turna kuşu sürüsü zannetmektedirler:

Pertâb ile halkalansa ejder

Hoş geldi sâf-ı küleng derler 
(Büyük yılanlar önlerine sıçrayarak halkalansa; "Ne güzel, turna kuşu sürüsüne rast geldik.” derlerdi.)

\section{Mâkiyân (Tavuk)}

Divan şiirinde mâkiyân adıyla anılan tavuk, kısa ve kalın gagalı, kısa kanatlı ve hızlı kanat çırpan tıknaz kuşlardandır. Şiirlerde daha çok gıda maddesi olarak yer alır. Civciv halinde iken pek sevimli olsa da büyüdükçe hantallaşır. Tavuk yumurtasının atış talimlerinde hedef olarak dikildiği şiirlerde bahsedilir. Kasidelerde övülen sultanın karşısındaki sultanların da tavuklara benzediği yer alır (Ceylan, 2015: 115). Ayrıca İstanbul Çarşıkapı'da yer alan, Tavuk Pazarı olarak anılan pazar yerindeki kahvehaneler halk şairlerinin toplanma mekânları olarak bilinmektedir (Ceylan, 2015: 112).

Şeyh Gâlib, Hüsn ü Aşk'ta tavuğu bir beytinde kullanmıştır; fakat bu kullanımı onun bir Sebk-i Hindî şairi olarak yalnızca ince mazmunlar, girift hayaller ve soyut, kapalı şiirler peşinde olmadığını, şiirinde somut, halk söyleyişlerine benzer ifadeler kullandığını ispat eder gibidir. Galib, Der Beyân-ı Mâhiyyeti Şâi’rî (Şairliğin Mahiyeti Hakkında) bölümünde şairlerin nasıl şiir yazması gerektiğini anlatırken iki üç güzel kelimeyi bir araya getirerek güzel şiir yazdığını zanneden müteşairleri bir yumurta yumurtlamak için kıyametler koparan şamatacı tavuklara benzetmiş, onların şiirlerini ve şairliğinin önemsizliğini bu ilginç teşbihle vurgulamak istemiştir:

Mânende-i mâkiyân-ı garrâ

Yek beyze hezâr fahr ü da'vâ

((Bu süslü ve içi boş kelimeleri bir araya getirerek şïr yazdiğını zannedenler), bir yumurta yumurtlamak için klyametler koparan şamatacı tavuklar gibidirler.)

\section{Nesr- Ukab (Kartal)}

Arapça ukâb ve nesr mânâsına gelen kimi Türk lehçelerinde bürküt denilen kartal, kuşların kralı kabul edilir. Kartalın şiirimizdeki en yaygın kullanım alanı gökyüzü ile ilgilidir. Dokuz kat gökyüzünün bir mevlevîhâne olduğunu ima etmek için bütün ylldızlarıyla gökyüzünde dönen nesr/ukâb (kartal takım yıldızı), kanatlarını açarak sema eden bir semâzene benzetilir.

Mânend-i ukâb eyle pervâz

Ol pûta-i imtihânda mümtâz

(1596)

(Kartal gibi uç ve bu imtihan potasında yükseklere torman.)

Gâlib’in Hüsn ü Aşk'ındaki en ilgi çekici söylemlerinden biri olan ve onun hayal gücünün zenginliğini gösteren imgelerden biri de Ateş Denizi imgesidir. Gâlib, hikâyesinde aslında içinde yaşadığı tüm engelleri, belaları, gamları mübalağalı, mecazlı, tezatlı ve istiareli üslupla yarattığı imgelerle tablolaştırmıştır. Çünkü bu resm ettiği ateş denizi, aslında "gam ateşi”dir. Mesnevinin Sıfât-ı Ân Âteş (Ateşin Tanımı) bölümünde Aşk ve Gayret’in yolu ateş denizine düşer. Gâlib bu anda, Gayret’in dilinden Aşk'a bir "imtihan potası" içinde olduğunu, fanîlik ateşinden kaçarsa "arslanın karnına girme (dünyaya bağlanma) tehlikesine uğrayacağını ihtar eder. Sonuçta bu ikazı dikkate alan Aşk, Berd ayeti (Ey ateş, İbrahim'e serin ve esenlikli ol. Enbiya S.69) ne benzeyen Âh kılıcı, Aşkar (Doru At) ve Gayret ile birlikte, o "ateşten yolu, meltem yeli gibi geçerler." Bu teşbih aslında çetin zorlukları kolayca aşan insanın bir soyutlamasıdır (Genç, 2004: s.y.).

Nesr-i felek indi âşiyâna

Gül-gonca hümâya oldı lâne 
(Kartal, (gökyüzünden inip) yeryüzünde yuvalandı; gül goncası da Hüma kuşuna yuva oldu.)

Kartal, yuvasını sarp ve yüksek yerlere yapan bir kuştur. Yumurtalarını ve yavrularını çok sarp kayalıkların en yükseğinde bulundurur. Şair, Der Vasf-ı Bahar (Bahar Hakkında) bölümünde, baharla birikte yeryüzü bir cennete dönüştüğü için kuşların kralı kartalın gökyüzünden inip yeryüzünde yuvalandığını belirtilir.

İki beyit dışında bu kuşu 1361. beyitte de görmekteyiz.

\section{7. Şâhin}

Av kuşlarının en önemlilerinden biridir. Şiirimizde şahin etrafında kurulan hayallerin hemen hemen tamamı onun yırtıcı bir avcı kuş özelliğinin etrafında şekillenir. Yüksekten aşağıya şiddetle iner, avının etrafında dönmez, doğruca avının üzerine atılır. Bu sırada fazla heyecanlanarak kendini yere çarptıgı ve bu yüzden öldüğü olur. Başı büyük, gözleri iri, göğsü geniştir. Av avlamadaki mahareti dolayısıyla ava giderken kolda taşınır (Öner, 2008: 560).

Her râhda eyleyip tekâpû

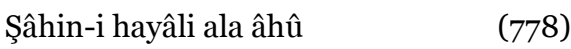

(Hayalinin şahini her yolda her bayırda uçar durur ve (şïr ve mânâ) ceylanın avlayıverir.)

Gâlib, mesnevide şairliğin nasıl olması gerektiğini anlattığı Der-Beyân-ı Mâhiyyet-i Şâi’ri bölümünde, şahinin avcılık yönünden istifade ederek şairin, hayal şahinini her mekânda uçurması gerektiğini şiir ve mânâ ceylanının ancak böyle avlanabileceğini belirtir.

Şâhin degilim ki edip âheng

Pervâz edeyim hezâr-ferseng ～(1585)

(Şahin değilim ki kanatlanıp bir çırpıda binlerce fersah yol alayım!)

Yolu ateş denizine düşen Aşk, çaresizliğini gözyaşları içinde atı Aşkar ile paylaşmaktadır. Önce Gayret gibi kanatları olmadığı için bu ateş deniziyle baş edemeyeceğinden bahseder. Sonra da içinde bulunduğu durumu biraz daha tasvir edebilmek adına şahinin uzun müddet havada kalma özelliğinden istifade ederek kanatları olmadığı için bu denizi geçemeyeceğini vurgular.

\section{8. Şehbâz (Doğan)}

Yırtıcı kuşların en bilinenidir. Arap ve Rum diyarından ziyade Türkistan'da yaşadığına inanılır. Türkistan sultanlarının doğanla avlanma geleneği vardır. Diğer yırtıcı kuşlar gibi Türk mitolojisinde önemli bir yere sahiptir. İhtişamı, kudreti ve muzafferiyeti temsil eden doğan divan şiirinin en önemli kuşlarından biridir. Aynı zamanda divan şiirinde bâz, şahbâz ve şâhin pek çok sözlüğün de verdiği çelişkili bilgilerle karıştırılmaktadır (Ceylan, 2015: 85-86). Doğan; şiirlerde baykuş, karga, sinek gibi uçanlarla mukayese unsuru olarak da kullanılmaktadır.

Şeyh Gâlib, Sebeb-i Telif bölümünde Nâbî’nin Hayrâbâd mesnevisinden bahsederken Nâbî’nin hırsızı padişahla bir tutmasını eleştirmiş, hırsızın padişahla bir olmayacağını belirtmek için padişahı doğan kuşuna, hırsızı da baykuş ve kaza teşbih etmiştir: 
Olsa ne kadar şikeste-pervâz

Uymaz yine kûf u kaza şehbâz

(Ne kadar kanadı kurık da olsa, doğan (Muhammet Nur Doğan mesnevinin çevirisinde bu kuşu şahin olarak almış) yine de baykuş ve kaz ile birlikte olmaz.)

Doğan, avcı olması, acımasızlı̆̆ı ve yüksekten uçması sebebiyle sevgilinin benzetilenidir. Sevgilinin gözleri, yan bakışı ve kâkülleri genelde doğan ile teşbih edilir (Ceylan, 2015: 92). Şeyh Gâlib, Der Vasf1 Hüsn (Hüsn'ü Anlatış) bölümünde de Hüsn’ün gözlerini doğana teşbih etmiştir:

Hayret-dih-i cân o çeşm-i şehbâz

Âhû-yı füsûn kebûter-i nâz

(O, alıcı doğana benzeyen gözü, can (kuşun)u şaşkınlığa düşürürdü; büyüleyiş ceylanıydı, naz güverciniydi.)

Behâne-i Dîger Engîhten (Gayretin Başka Bir Cevap Bulması) bölümünde Gayret, Aşk'a Hüsn’ü kabileden istemesinin uygun olacağını söylerken Aşk'ın avcı olduğunu belirtmek için onu doğan kuşuna benzetmiştir. Şeyh Gâlib, Aşk’’ anlatırken onun savaşçılık özelliğini eserin birçok yerinde vurgulamıştır:

Var iste kabîle içre yârin

Şehbâzsın al hemân şikârın

(1161)

(“Var git, sevgilini kabilenden iste. Sen alıcı doğansın; kapıver hemen avını.”)

Şair Der Vasf-ı Esb (At Hakkında) bölümünde Aşkar’ı tasvir ederken onun kulaklarının doğanın sorgucuna benzediğini söyler. Atın kulaklarından bile doğan kuşu gibi savaşçı olduğu anlaşılmaktadır:

İki kulağı çeleng-i şehbâz

Gerdânı sürâhî-i ser-efrâz

(1496)

(İki kulağı, sanki alıcı doğanın başındaki sorguç; gerdanı ise uzun boyunlu bir sürahi...)

Doğan, söz konusu beyitler dışında 265, 671, 813 ve 1472 numaralı beyitlerde de geçmektedir.

\section{Tâvûs}

Türklerde alakuş, gelin kuşu ya da Tanrı kuşu olarak bilinen tavus kuşunun kökeni Hindistan olarak gösterilir. Sülüngiller familyasındandır. Cennet kuşu olarak da bilinir. Rengarenk kanatları, başındaki sorgucu ile diğer kuşlardan hemen ayrılır. Pek çok şairin bahsettiği tavus; iffet, renk, gösteriş, ihtişam, güzellik, itibar, kendinin beğenme ve böbürlenme sembolüdür. Divan şiirinde öncelikle güzelliğiyle bilinir (Ceylan, 2015: 228). Hazreti Adem'in yasak elmayı yemesine sebep olduğu için cennetten kovulduğu hikâyesi de şiirlerde yer bulmuştur.

Şeyh Gâlib; yolculuğu esnasında Aşk'a sevgilisi Hüsn tarafından hediye edilen Aşkar’ı Der Vasf-ı Esb (At Hakkında) bölümünde ayrıntılı bir şekilde tasvir eder. Bu tasvirlerinde onu güzellik, güç, hız gibi çeşitli özelliklerle över ve ona bir kutsiyet atfeder. Aşkar'ı uçabildiğinden ötürü kuş teşbihleriyle de vasfeder. Onu kırmızı renginden ve güzelliğinden ötürü tavus kuşuna benzetmiştir:

Tâvûs-ı behişt ü şir-i garra

$\mathrm{Al}$ câmeli bir arûs-ı zîbâ

(Cennet tavusu, gösterişli bir aslan; al fistanl bir güzel gelin...) 
Sevgilinin zülüf ve kâkülleri, tavusun "münakkaş" kelimesiyle nitelendirilmesini sağlayan kuyruğuna (düm-i tâvûs) ve kanatlarına (per-i tâvûs) benzetilmiştir. Bu teşbihlerde zülfün üzerine düştügü yanaklar cennet olarak düşünülür. Dövünmekten dolayı göğsü yaralardan morarmış ve kızarmış olan âşık da tüylerindeki renk cümbüşünden hareketle tavusa benzetilir (Ceylan, 2011: 184-185). Der Vasf-ı Hüsn (Hüsn’ü Anlatış) bölümünde başkahraman Hüsn’ün bütün özellikleri divan şiirindeki ideal kadın sevgiliye göre tasvir edilmiştir. Gözleri, saçları, yüzü, hatta hayaliyle o; bütün kainatın en güzelidir, "baştan aşağı incelik ve hoşluk; tepeden tırnağa güzellik ve tatllıktır" (471. beyit). Gül renkli elbisesi de tavus kanıyla boyanmış gibi kırmızıdır:

Gül-gûn kabâsı hûn-ı tâvûs

Nâzında hezâr reng mahsûs

(Gül renkli elbisesi (sanki) tavus kanıla boyanmıştı; nazlanışında binlerce oyun, binlerce düzen (hile) sezilmedeydi.)

Şair, Hüsn'ü resmettikten hemen sonra Der Vasf-ı Aşk (Aşk’ı Anlatış) bölümünde Aşk'ın özelliklerini tarif etmektedir. Aşk’nn tüm özellikleri de Hüsn gibi idealdir; fakat Hüsn gül bahçesinin en güzeliyken Aşk savaş meydanının en güçlüsüdür; şair onun fiziksel özelliklerini tasvir ederken dahi savaşçılığını vurgulamaktadır. Bu beyitte ise Aşk'ın kılıcını kan cennetinde salınan tavusa benzetmiş; hem kılıcının kızıllı̆̆ını vurgulamış hem de tavusun cennet kuşu olmasına telmihte bulunmuştur:

Şemşîri behişt-i hûna tâvûs

Şeş-perri künişt-i dîne nâkûs

(Kılıcı kan cennetinde salınan tavus; şeşperi (topuzu) da din tapınağının tepesine asılı çandı.)

Şeyh Gâlib Çin Sahili’nde Aşk ve Hüşrübâ’nın eğlence meclisini (Meclis-i Îş) anlatırken mecliste bulunan tüm eğlence unsurlarını ayrıntılarıyla tasvir etmiştir. Şarabın insanın hâlet-i ruhiyesinde yaptığı etkileri de çarpıcı biçimde açıklayan şair, şarabı renginden ve tavus kuşunun rengarenk tüyleri gibi insanı bambaşka ruh hâllerine sokmasından ötürü tavus kanına benzetmiştir:

Sahbâ velî saf hûn-1 tâvûs

Keyfinde hezâr reng mahsûs (1657)

(Şarap, fakat tavus kanı; rengârenk, çeşit çeşit keyifler vermede.)

Tavus kuşu küçük otlar ve böceklerle beslenir. İslamiyete göre eti haramdır, avlanılıp yenmesi uygun görülmemiştir. Şeyh Gâlib, Mânâ Mesiresi’ni anlatırken orada bulunan tüm varlıkları normalden farklı veya daha iyi bir biçimde tasvir etmiştir. Kuşları da ayrıntılı bir biçimde anlatan Gâlib, av kuşu olan şahinlerin ava alışık olmadığını, sülünlerin tavus kuşları tarafından avlandığını söylemiştir:

Şehbâzı değil şikâra me'nûs

Sayd eyler idi tezervi tâvûs

((Mânâ Mesiresi’nin) şahinleri ava alışık değildi; orada sülünleri tavus kuşları avlıyordu.)

Hüsn ü Aşk'ın sonunda şairin ruh hâlinden bahsettiği ve şiirini anlattığı Hakîkat-i Hâl ve Hâtime-i Kitâb (Durumun Gerçeği ve Kitabın Sonu) bölümü bulunmaktadır. Bu bölümde şair; eser bittikten sonra ne hissettiğini tüm kalbiyle kaleme almış, tevazu göstererek yazdığı eserin kendine ait olmadığını, onun ilahi bir ilham ile kaleminden döküldüğünü dile getirmiştir. Şiirde en iyiye ulaşmanın zorluğunu cennet tavusu ifadesi ile vurgulayan şair, artık yazacak takati kalmadığını belirtmiştir. 
Tâvûs-ı behişte eyledim nâz

Ammâ ki yok iktidâr-ı pervâz ～～(2032)

(Bense cennet tavusuna özenmiştim, fakat uçmaya takat kalmamıştı.)

\section{2o. Tezerv, Süğlün (Sülün)}

Divan edebiyatında daha çok tezerv adıyla geçen, süğlün adıyla da anılan sülün, tavusla birlikte saltanatı ya da ölümsüzlüğü simgeler. Çekingen ama heyecanlı tavırları nedeniyle tereddütler içinde kalmış, ne yapacağını bilemeyen akılla bağlantısı kurulur (Ceylan, 2015: 221). Avlanması zor bir kuştur. Divan şiirinde öncelikle av kuşu olarak geçer. Ayrıca güzelliği ve nazlı yürüyüşü ile de adından söz edilmiştir (Öner, 2008: 558). Şeyh Gâlib Der Vasf- 1 Tîğ (Kılıç Hakkında) bölümünde kılıcı güzelliğinden ötürü sülüne, yeşile yakın siyah gövdesi ve ucundan akan kan sebebi ile gagası kırmızı bir papağana (Doğan, 2017: 341), kesici ve kan dökücü olması nedeniyle de doğana benzetmiştir:

Bir tûtî-i sebz-i hûn-pâlâ

Şehbâz veli tezerv-sîmâ （1472）

(Gagasından kan süzülen yeşil bir papağan; sülün görünüşlü bir doğan kuşu...)

Şair, Aşkar’ı da güzelliğinden ötürü sülüne benzetmiştir:

Süğlün gibi bir semend-i gül-gûn

Gül-zâr-ı behişt ü kulzüm-i hûn （1481)

(Gül renkli, sülün gibi bir at... Sanki cennetin gül bahçesi, ya da kan denizi...)

Sülün, avcı özelliği ve estetik oluşunun yanı sıra aşık-sevgili bağlamındaki benzetmelerde yoğun olarak kullanılmıştır. “Âşığın gönlü veya sevgili için benzetilen olur. Güzel salınışı ile de sevgiliyi andırır.” (Pala, 2008: 455).

Şeyh Gâlib, Muhabbetoğullarının sıradışı baharlarını tarif ederken selvi ağacının âşık olduğundan dolayı sülünü kanatları altına almadığından bahseder:

Kimdir düşüren hevâya servi

Almaz kanad altına tezervi (282)

(Servi ağacını aşka düşüren kimdir ki, sülünü kanatları altına almıyor?)

“Bülbül” başlığında açıklandığı gibi sülün de Sühan’ın kılığına girerek haber getirdiği kuşlardan biridir. Âgâhî Dâden-i Sühan Be-Sûret-i Tezerv (Sühan'ın Sülün Kılığına Girerek Haber Getirmesi) bölümünde Sühan, Aşk’a Hüşrüba’nın onu Zatussuver kalesine götüreceğini haber vermiştir:

Gûş etdi ki bir tezerv-i dil-keş

Bu gûne verir peyâm-ı âteş (1687)

(Aşk, uzun boylu güzel bir sülünün ateş gibi (yakıcı) haberler getirdiğini işitti.)

Söz konusu beyitler dışında sülün, 671, 1699 ve 1995 numaralı beyitlerde de geçmektedir.

\section{Tîhû (Çil Kuşu)}

Etinin lezzeti ile bilinen av kuşlarından biridir. Mesnevide iki yerde bu kuşu görmekteyiz. 
Tîhûları sûsmâr olur hep

Dürrâcları perende akrep （264）

(Orada) çil kuşları hep kertenkeleye döner; keklikleri, bütün kanath krep olurdu.)

Sıfât-ı Şikâr-ı Îşân (Avlanmalarının Tarifi) bölümünde Muhabbetoğulları'nın ava gittikleri vakit çil kuşlarının kertenkeleye döndüğü ifadesiyle karşılaşırız.

Baruta şitâb ederdi âhû

Ağız otına gelirdi tîhû (1367)

(Ceylanlar barut (ateşine) can atıyor; çil kuşları ağız otunu yemeye geliyorlardı.)

Şair, Der Sıfat-ı Şeb ve Şiddet-i Şitâ (Gece ve Kışın Şiddeti Hakkında) bölümünde çil kuşunun yeminin ağız oyu olduğu belirtilmiştir. Gece öyle soğuk ve kış o kadar şiddetlidir ki ceylanlar ısınmak için barut ateşine doğru koşmakta; çil kuşları ise sıcaklığından istifade etmek üzere, barutu yem gibi yemeye çalışmaktadırlar (Doğan, 2017: 317).

\section{Tûtî (Papağan)}

Divan edebiyatında tûtî ya da bebgâ olarak anılan papağan, halk arasında dudu kuşu olarak da bilinir. Anavatanı Hindistan kabul edilir. Evcilleştirilmeye müsait olan kuşlardandır. İnsan sesini taklit etmesiyle bilinir. Konuşmayı öğrenmesi için kafesine bir ayna konarak ayna arkasından konuşulur. Papağan aynada gördüğü aksini konuşuyor zanneder ve kısa zamanda konuşmayı öğrenir. Konuşmayı öğrendikçe sevdiği şekerlerle ödüllendirilir. Papağan, divan şiirinde ayna ve şekerle ilgili telmihlerle sık sık kullanılır (Ceylan, 2015: 199). Şeyh Gâlib, Der Vasf-ı Bahâr (Baharı Anlatış) bölümünde baharın gelişiyle beraber bereketlenen bahçenin şekerle dolduğunu; arıların ve papağanların bu şekerlerin üzerinde uçtuğunu belirtir:

Ebr eyledi bâğı tûşe-gencûr

Şekkerde uçardı tûtî zenbûr ( 608)

(Bulut, bahçeyi rızık hazinesi yaptı; papağanlar ve arılar şekerin üzerinde uçmaktaydı.)

Papağanın tatlı tatlı konuşması divan şiirinde sevgilinin benzetileni olarak kullanılmıştır. Papağan aşığa teşbih edildiğinde ise sevgilinin dudakları şekere benzetilmiştir. Şeyh Gâlib Der Çigûnegî-i EzMahabbet-i Îşân (Sevgililerin Keyfiyetinden Bir Haber) bölümünde Aşk'a âşı olan Hüsn'ün şeker dudaklı bir sevgili olmayı bırakıp âşık bir papağana dönüştüğünü belirtmiştir:

Tûtî görünürdi ol şeker-leb

Ma'şûk idi âşıâne-meşreb ( 387)

(O şeker dudaklı (Hüsn) papağan olmuş; sevgili, âşık gibi davranmaya başlamıştır.)

Şair, Mânâ Mesiresi’ni tasvir ederken erik ağaçlarının gönül hoşluğunda yeşerdiğini, bu yüzden de meyvelerinin tatlı tatlı konuşan papağan kuşlarına benzediğini söylemiştir. Erikler ve papağanlar arasında renk yönünden teşbih oluşturmuş; eriğin tatlllığı ile papağanın tatlı yemesi arasında ilgi kurmuş̧tur:

Ser-sebz-i safâ dıraht-ı âlû

Her meyvesi tûtî-i şeker-gû (663)

(Gönül hoşluğunda yeşeren erik ağacının meyveleri, tath tatlı konuşan papağan kuşları idi.) 
Papağanın tüylerindeki hakim renkler kırmızı ve yeşildir. Al papağan sevgilinin diline, dudağına, laleye, içi şarap dolu kadehe teşbih olurken yüzde yeni bitmiş ayva tüyleri, taze ağaç yaprakları, yeşil elbiseler giymiş sevgili, aşı̆̆ın mezarında biten otlar vb. de yeşil tûtîye teşbih edilir (Ceylan, 2015: 196-197).

Şair, "Baharı Anlatış” bölümünde baharın gelmesiyle yeşeren toprağı papağan kanadına teşbih etmiştir:

Nevrûz edicek hevâyı nem-nâk

Tûtî peri oldı sebze-i hâk （603)

(Nevruz, havayı bu kadar nemlendirince, toprağın yeşilliği papağan kanadı gibi oldu.)

Şeyh Gâlib; Der Vasf-ı Esb (At Hakkında) bölümünde de Aşkar’ı kırmızı rengi, konuşabilmesi ve uçabilmesi yönüyle papağana teşbih etmiştir:

Tûtî gibi gerçi âl-câme

Hâmûş-kün-i kümeyt-i hâme ～(1505)

(Kendisi papağan gibi al fistanlı ama, kalemin doru atım bile susturuyor.)

Papağan, diğer bütün kuşlar gibi kafeste beslenir. Kafese hapsedilmesinin sebebi de kendisini diğer kuşlardan ayıran özelliği olan konuşmasıdır. Kimi zaman da beden kafesi içinde kalmış olan gönül veya şairane yaradılış/tab', papağana benzetilir (Ceylan, 2015: 197-198).

Muvâfakat-ı Gayret Bâ Aşk (Gayret’in Aşk'a Uyması) bölümünde Gayret, gönlünde saklı sırları papağana ve dudaklarını da kafesin kapılarına benzetmiş, içindekileri bir kez daha Aşk’a anlatmayacağını söylemiştir:

Bir dahı dehânım etmeyim bâz

Kalsin bu kafesde tûtî-i râz (1181)

(Bir daha ağzımın kapıların açmayacağım... İçimdeki sırların papağanı bu kafeste kalakalsın!)

Divan şiirinde papağanla adı çok sık anılan iki kuş bulunmaktadır. Biri güzel ötüşüyle papağanın konuşmasına paralellik kurulan bülbül, diğeri ise çirkin sesiyle tezat kurulan kargadır (Ceylan, 2015: 204). Şeyh Gâlib’in de Resîden-i Aşk Be Sâhil-i Çîn (Aşk’nn Çin Sahiline Varışı) bölümünde bu geleneksel kullanımı hatırlatan fakat ondan daha farklı olan bir teşbihi vardır. Çin sahilindeki bülbüller ve papağanlar o kadar üstün kabiliyetlidir ki, iki kuş türü de birbirinin maharetini sergileyebilmektedir:

Bülbülleri tûtî-i sühân-sâz

Bebgâları sûz u sâza hem-râz (1606)

(Bülbülleri konuşan papağanlar gibiydi; papağanları da yanıp yakılışa ve ötüşe aşina idi.)

“Bülbül” başlığında da bahsedildiği üzere papağan, Sühan’ın kılığına girdiği kuşlardan biridir. Âgâhî Dâden-i Sühan Be-Sûret-i Tûtî (Sühan'ın Papağan Kılığına Girerek Haber Vermesi) bölümünde Sühan, al gagalı yeşil bir papağan olarak karşımıza çıkar. Yeşil renginin özellikle belirtilmesinin sebebi masallarda rastlandığı gibi yardımcı/ Hızır rolünün Sühan’a yüklenmesidir:

Bir tûtî-i sebz-i âl-minkâr

Bir şâhda eyler anı tekrâr （1619）

(Al gagalı yeşil bir papağan, bir dala konmuş, durmadan şu sözleri tekrarlıyordu: ) 
Şeyh Gâlib’in Sühan ile Hızır tipini hatırlatmak istediği aşağıdaki beyitte de görülebilir:

Ol tûtî-i sebz edip bunı fâş

Hızr-ı reh-i gayba oldı yoldâş

(O yeşil papağan bu sırrı açı̆̆a vurduktan sonra gayb yolunun Hızırina yoldaş olup gözden kayboldu.)

Âgâhî Dâden-i Sühan Be Sûret-i Tezerv (Sühan'ın Sülün Kılığına Girerek Haber Vermesi) bölümünde de sülün kuşu konuşabilmesiyle papağana teşbih edilmektedir:

Duydun ne dedi tezerv-i tûtî

Vermem sana bu kadar sükûtı

(1699)

(Papağan gibi konuşan sülünün ne dediğini duydun! Bu derece düşmeyi sana yakıştıramam!)

Papağan bu beyitler dışında 1472 ve 1995 numaralı beyitlerde de geçmektedir.

\section{Sonuç}

Hüsn ü Aşk metni, somuttan soyuta uzanan birçok anlam katmanını içinde barındırır. Bu katmanlar muhtelif yorum ve okumalara açı; aynı zamanda da gerçek dünya ile bağlantılı bir durum arz eder. Hüsn ü Aşk, Osmanlı şiir kuşlarını kullanması yönüyle de zengin bir mesnevidir. Metinde yer alan kuşların kimi mecaz, telmih, intak gibi sanatlar yoluyla ele alınıp işlenmiş kimi zaman da şairin elinde değişik konular için birer araç vazifesi görmüştür. Eserde, 22 kuşun ismi geçmektedir. Şair, kuşları geleneksel kullanıma uygun şekilde kullandığı gibi çok farklı teşbihlerle de okuyucuya sunar. Hüsn'ün geceleri dolaşmasını yarasa ile ilişkilendirir. Viraneleri mesken tutmuş baykuşu bir beyitte harabeden nefret eder hâlde görür okuyucu. Muhabbetoğullarının tasvir edildiği bölümlerde ise çizilen tablo, zıtlıklar üzerine kurulmuştur. Bahsedilen varlıklar, özellikle kuşlar, sahip oldukları vasıflarının zıttıyla tavsif edilmişlerdir. Güzelliği, musikiyle olan alakası ve hazin bir sonla biten hikâyesinden ötürü şiirimizde güzel, zarif kullanımlar doğuran kaknüs, Hüsn ü Aşk’ta eleştirinin yoğun olduğu bir bölümde ortaya çıkar. Yeni mazmunun olmadığını iddia eden ve şairlerin yalnızca hırsızlık yaparak şiir yazabileceğini söyleyen kahvehane şairleri Gâlib’e göre "ateşler, dumanlar içinde pinekleyip boş sözler yumurtlayan kaknüs kuşu”ndan farksızdır. Şair, tavuğu da böyle bir bağlamda kullanır. Şairlerin nasıl şiir yazması gerektiğini anlatırken iki üç güzel kelimeyi bir araya getirerek güzel şiir yazdığını zanneden müteşairleri bir yumurta yumurtlamak için kıyametler koparan şamatacı tavuklara benzetir, onların şiirlerini ve şairliğinin önemsizliğini bu ilginç teşbihle vurgular. Tâvus kuşunun şarap ve kılıçla olan ilişkisi de dikkat çekicidir.

Şeyh Gâlib’in Hüsn ü Aşk’ta kuşları çok farklı hayaller içerisinde kullanması onun gelenekten farklı olmaya çalışmasıyla açıklanabilir. Galib’e göre şair, şiirin çıktığı bütün yollarda koşturduktan sonra "hayâl şâhini” şiir ceylanını avlamalıdır. Şair, kuşların özelliklerinden istifade ettiği beyitlerinde söz hazinesinin bütün imkânlarını kullanmış, kendine has özgün, yeni bir lugat ve yeni bir söyleyişle Hind Üslûbunun en güzel örneklerini vermiştir.

\section{Kaynakça}

Akalın, S. (1993). Türk Folklorunda Kuşlar. Ankara: Kültür Bakanlığı Yayınları.

Akın, E., Akın, E. ve Ayverdi G. Şeyh Galib Divanında Mitolojik ve Efsanevî Kuşlar. Türk İslam Dünyası Sosyal Araştırmalar Dergisi, 9, 82-98. 
Akün, Ö. F. (1994). Divân Edebiyatı. Türk Diyanet Vakf İslam Ansiklopedisi içinde. Erişim adresi https://islamansiklopedisi.org.tr/divan-edebiyati.

Bingöl, U. (2013). Hüsn ü Aşk Mesnevisinde Şahısların Dünyası. Uluslararası Türkçe Edebiyat Kültür Eğitim Dergisi, 2/4, 206-229.

Ceylan, Ö. (2003). Şahkulu Bektâşî Tekkesi Şeyhi Mustafa Azbî Baba ve "Murgnâme” Kasîdesi. Journal Of Turkish Studies, 27(1), 229-249.

Ceylan, Ö. (2015). Kuş Dili. İstanbul: Kapı.

Ceylan, Ö. (2019). Tavus. Türk Diyanet Vakfi İslam Ansiklopedisi içinde. Erişim adresi https://islamansiklopedisi.org.tr/tavus.

Çoruhlu, Y. (2002). Türk Mitolojisinin Anahatları. İstanbul: Kabalcı Yayınları.

Doğan, M. N. (2015). Şeyh Gâlib Hüsn ü Aşk (8’inci bs.). İstanbul: Yelkenli Yayınları.

Genç, İ. (2004). Hüsn ü Aşk Kahraman Aşk’n Manevî Yolculuğunun Retorik Boyutu. Kırıkkale Üniversitesi I. Ulusal Sosyal Bilimler Sempozyumu, 9-10 Aralık 2014.

Güler, Z. (2014). Şeyh Galib Divaninda Anka-Simurg Sembolü. İnternational Journal of Language Academy, 2/1, 63-72.

Kafesoğlu, İ. (1986). Türk Milli Kültürü. İstanbul: Boğaziçi Yayınları.

Kaplan, M. (1979). Bülbül. Milli Eğitim Bakanlı̆̆ İslam Ansiklopedisi içinde. (5. bs., Cilt 2, 832-834. ss.)

Kurnaz, C. (1992). Bülbül. Türk Diyanet Vakfi İslam Ansiklopedisi içinde. Erişim adresi https://islamansiklopedisi.org.tr/bulbul.

Kurnaz, C. (2004). Eski Türk Edebiyatı. Ankara: Gazi Kitabevi.

Onay, A. T. (1996). Eski Türk Edebiyatında Mazmunlar. İstanbul: Milli Eğitim Basımevi.

Ögel, B. (1993). Türk Mitolojisi I. Ankara: Türk Tarih Kurumu.

Öner, E. (2008). Gevheri Divaninda Kuşlar. Uluslararası Sosyal Araştırmalar Dergisi, 1/5, 554-575.

Özek, A., Karaman, H., Turgut, A., Çağrıcı, M., Dönmez, İ. K. ve Gümüş, S. (2008). Kur'ân-ı Kerîm ve Açıklamalı Meâli (11'innci bs.). Ankara: Türk Diyanet Vakfı Yayınları.

Pala, İ. (2008). Ansiklopedik Divan Şiïi Sözlüğü. İstanbul: Kapı yayınları.

Savran, Ö., Tıraş, Y. C. (2017). Sebk-i Hindî’de Kuşlar. E. Gürsoy Naskali, A. Şeker (Ed.), Kuş Dili Dilde, Edebiyatta ve Sanatta Kuşlar içinde ( 43-112. ss.) İstanbul: Dergâh.

Tanç, N. (2013). Alımlama Estetiği Işığında Hüsn ü Aşkinn Poetik Değeri: Suhan. Turkish Studies, International Periodical For the Language Literature and History of Turkish or Turkic, 8/9, 23512360.

Ülgen, A. (1994). Kuş Evleri. Tarih ve Medeniyet Dergisi, 7, 55-58. 